\title{
Pupuk Organik Cair Dari Limbah Industri Tempe
}

\author{
Joko Prasetio ${ }^{1)}$ Sri Widyastuti ${ }^{2)}$ \\ ${ }^{1) 2}$ Program Studi Teknik Lingkungan, Fakultas Teknik, Universitas PGRI Adi Buana Surabaya \\ E-mail: jokovick.jp@gmail.com
}

\begin{abstract}
Abstrak
Penelitian ini bertujuan untuk membuat pupuk organik cair dari limbah cair indusrti tempe dengan penambahan bonggol pisang dan bioaktivator EM4. Kualitas pupuk organik cair yang dihasilkan ditentukan berdasarkan kandungan $\mathrm{P}, \mathrm{C}$ Organik, $\mathrm{pH}$ dan $\mathrm{N}$, dibandingkan dengan Permentan No 01 Tahun 2019. Pembuatan pupuk organik cair dilakukan dengan proses penambahan bonggol pisang yang dihaluskan dan ditambah bioaktivator EM4 dengan variasi $75 \mathrm{ml}, 100 \mathrm{ml}$, dan $125 \mathrm{ml}$. Hasil yang diperoleh pupuk organik cair dengan penambahan EM4 $75 \mathrm{ml}$ adalah $\mathrm{P}=3.38 \%, \mathrm{C}$ Organik $=2.33 \%, \mathrm{pH}=3.74$ dan $\mathrm{N}=1.10$, pupuk organic cair dengan penambahan EM4 $100 \mathrm{ml}$ adalah $\mathrm{P}=3.53 \%, \mathrm{C}$ Organik $=2.33 \%, \mathrm{pH}=3.66$ dan $\mathrm{N}=1.11 \%$, dan pupuk organik cair dengan penambahan EM4 $125 \mathrm{ml}$ adalah $\mathrm{P}=3.66 \%, \mathrm{C}$ Organik $=2.91 \%, \mathrm{pH}=3.61$ dan $\mathrm{N}=1.14 \%$. Dari semua pupuk organik cair yang dihasilkan hanya kadar P yang memenuhi Permentan No 01 Tahun 2019 tentang baku mutu pupuk organik cair.
\end{abstract}

Kata Kunci: Bonggol Pisang, Limbah Cair Industri Tempe, Pupuk Organik Cair

\begin{abstract}
This study aims to make liquid organic fertilizer from tempeh indusrti liquid waste with the addition of banana humps and EM4 bioactivator. The quality of the liquid organic fertilizer produced is determined based on the content of P, C Organic, $p H$ and N, compared with Permentan No.216 of 2019. Manufacture of liquid organic fertilizer carried out by adding mashed banana humps and added EM4 bioactivator with variations of $75 \mathrm{ml}, 10 \mathrm{ml}$, and $125 \mathrm{ml}$. The results obtained by liquid organic fertilizer with the addition of $75 \mathrm{ml} E M 4$ are $P=3.38 \%$, Organic $C=2.33 \%, p H=3.74$ and $N=1.10$, liquid organic fertilizer with the addition of EM4 $100 \mathrm{ml}$ is $P=3.53 \%$, Organic $C=2.33 \%, p H=3.66$ and $N=1.11 \%$ and liquid organic fertilizer with the addition of $125 \mathrm{ml} E M 4$ is $P=3.66 \%$, Organic $=C$ $2.91 \%, p H \backslash 3.61$ and $N=1.14 \%$. Of all the liquid organic fertilizers produced only the levels of $P$ and $N$ that meet Permentan No. 216 of 2019 regarding the quality standards of liquid organic fertilizer.
\end{abstract}

Keywords: Banana Weevil, Tempe Industry Liquid Waste, Liquid Organic Fertilizer

\section{PENDAHULUAN}

Gakoptindo (2018) mencatat volume produksi tahu dan tempe tidak berubah dari tahun lalu atau sekitar 4 juta ton. Secara komposisi, produksi tempe mendominasi sebesar $65 \%$ atau sebesar 2,6 juta dari keseluruhan produksi tempe dan tahu, sedangkan produksi tahu berkontribusi sebesar
1,4 juta ton. Produsen tempe berkontribusi sekitar $80 \%$ dari total produsen atau sekitar 120.000 unit produsen, sementara produsen tahu berjumlah sekitar 30.000 unit produsen.

Tempat produksi tempe kebanyakan terletak di daerah perumahan serta lingkungan penduduk dan masih banyak industri tempe skala rumah tangga yang belum memiliki pengolahan limbah yang baik (Sutrisno1996, 
dalam Adiprakoso, 2012). Limbah yang diperoleh dari proses pengolahan tempe dapat berupa limbah cair maupun limbah padat. Sebagian besar limbah padat yang berasal dari kulit kedelai, kedelai yang rusak dan mengambang dalam proses pencucian. Sedangkan limbah cair berasal dari proses perendaman dan perebusan kedelai yang biasanya langsung di buang ke badan air seperti sungai tanpa proses pengolahan terlebih dahulu. Salah satu cara pengolahan air limbah tempe adalah memanfaatkannya menjadi POC (Pupuk Organik Cair).

Besarnya beban pencemaran yang ditimbulkan menyebabkan gangguan yang cukup serius terutama untuk perairan disekitar industri tempe menimbulkan bau busuk dari limbah cair tempe dan jika dibuang ke sungai akan menurunkan kualitas air sungai. Limbah cair tempe tersebut memiliki kandungan senyawa kompleks terdiri dari protein sebesar $0,42 \%$, lemak $0,13 \%$, karbohidrat $0,11 \%$, air 98,87\%, kalsium 13,60 ppm, fosfor $1,74 \mathrm{ppm}$ dan besi 4,55 ppm. Jika dimanfaatkan secara tepat maka akan mengurangi pencemaran lingkungan dan menghilangkan sumber penyakit (Pawestri Farrah Diba, Eko Budi Susatyo dan Winarni Pratjojo, 2013).

Penambahan bonggol pisang diharapkan dapat berpengaruh terhadap kualitas pupuk organik cair karena adanya mikroba dan kandungan kimia yang terdapat pada bonggol pisang. Dalam bonggol pisang terdapat zat pengatur tumbuh giberelin dan sitokinin, serta terdapat 7 mikroba yang sangat berguna bagi tanaman yaitu Azospirillium, Azotobacter, Bacillus, Aeromonas, Aspergillus, mikroba pelarut fosfat dan mikrobia selulotik yang dapat dimanfaatkan sebagai pupuk cair (Maspary, 2012). Menurut Suhastyo (2011) di dalam bonggol pisang terkandung $\mathrm{C} / \mathrm{N}$ 2,2, Fe 0,09 ppm, dan Mg 800 ppm. Unsur kimia tersebut sangat berpengaruh terhadap pertumbuhan vegetatif tanaman khususnya pembentukan daun, hal ini sesuai penelitian dari Subhan (2004) bahwa kandungan Mg sangat berperan pada pembentukan daun hasil fotosintesis dan mempengaruhi warna daun yang lebih hijau.

Tabel 1. Komposisi Bonggol Pisang

\begin{tabular}{|c|l|l|l|}
\hline No & Komponen & Basah & Kering \\
\hline 1 & Kalori (kal) & 43 & 245 \\
\hline 2 & Protein $(\mathrm{g})$ & 0,6 & 3,4 \\
\hline 3 & Karbohidrat $(\mathrm{g})$ & 11,6 & 66,2 \\
\hline 4 & P (mg) & 60 & 150 \\
\hline \multicolumn{3}{|l|}{ Sumber :Direktorat Gizi Departemen Kesehatan R.I., (1996) } \\
\hline
\end{tabular}

Pada proses pengomposan sampah organik rumah tangga dengan menggunakan MOL bonggol pisang, diperoleh perlakuan yang paling cepat kematangan komposnya yakni selama 12 hari yaitu perlakuan dengan konsentrasi MOL $150 \mathrm{ml}$. Sedangkan Kualitas kompos terbaik yang diperoleh dengan memperhatikan parameter kualitas kompos adalah perlakuan MOL $500 \mathrm{ml}$ dengan kandungan $\mathrm{N}$-total $0,92 \%$, P2O5 1,30\%, dan $\mathrm{K} 2 \mathrm{O}$ sebesar 1,67\%. (Wahyudin dan Nurhidayatullah, 2018)
Hasil penelitian Wulandari et al. (2011),menyatakan bahwa pengaruh media terhadap berat kering total semai jabon $(A$. cadamba Miq.)menunjukkan bahwa perlakuan dengan penambahan kompos batang pisang memberikan pengaruh paling baik dibandingkan dengan perlakuan penambahan kompos ofer, andam, cocopeat dan guano. Penambahan kompos batang pisang mampu memberikan peningkatan berat kering total sebesar $177,3 \%$. Selain itu penambahan kompos batang pisang dapat meningkatkan tinggi semai jabon sebesar $57,3 \%$ 
dibandingkan kontrol. Proses pengomposan secara alami akan memakan waktu yang relatif lama yaitu sekitar 23 bulan bahkan 6-12 bulan. Pengomposan dapat berlangsung dengan fermentasi lebih cepat dengan bantuan mikroorganisme lokal.

Hasil analisis ragam penelitian Kusmiadi R, Khodijah NS dan dan Royalaitani, (2015) menunjukkan bahwa penggunaan gedebo pisang berpengaruh nyata terhadap sifat fisik pada peubah persentase kadar air kompos bulu ayam namun tidak berpengaruh pada peubah suhu. Sedangkan pada sifat kimia berpengaruh nyata pada peubah rasio $\mathrm{C} / \mathrm{N}$ dan kadar kalium (K) namun tidak berpengaruh pada peubah $\mathrm{pH}$, C-organik, N-total dan fosfor (P).

Proses pembuatan pupuk organik cair membutuhkan waktu yang lama untuk siap digunakan. Pada saat ini telah ditemukan bioaktivator untuk mempercepat proses pembuatan pupuk organik cair. EM4 (Effective Microorganisms) dan ragi tempe adalah jenis bioaktivator yang sudah di pasarkan sehingga mudah di dapatkan. EM4 mengandung beberapa mikroorganisme bakteri asam laktat (Lactobacillus sp.), Jamur fermentasi (Saccharomyces sp), bakteri fotosintetik (Rhodopseudomonas sp.) dan Actinomycetes yang dapa mempercepat proses fermentasi pada pembuatan pupuk organiK cair (Pawestri Farrah Diba, Eko Budi Susatyo dan Winarni Pratjojo, 2013.). Penambahan EM-4 pada limbah cair tempe adalah mengaktifkan bakteri pelarut,meningkatkan kandungan humus tanah lactobacillus sehingga mampu memfermentasikan bahan organik menjadi asam amino.

Untuk mengatasi masalah tersebut dalam penelitian ini adalah memanfaatkan limbah cair tempe sebagai bahan dasar pembuatan pupuk organik cair. Komponen terbesar limbah cair tempe yaitu protein ( $\mathrm{N}$-total) sebesar 226,06 $\mathrm{mg} / \mathrm{L}$ sampai $434,78 \mathrm{mg} / \mathrm{L}$, sehingga masuknya limbah cair tempe ke lingkungan perairan akan meningkatkan total nitrogen di perairan tersebut (Nurosid, 2011).

\section{METODE}

Dalam proses pembuatan pupuk organik cair yang pertama dilakukan adalah pembuatan reaktor dengan volume 5 liter yang dimodifikasi dengan memberi selang pada bagian atas agar bisa mengeluarkan gas hasil fermentasi. Selanjutnya adalah menyiapkan bahan yang akan digunakan sebagai bahan pembuat POC yaitu limbah cair industri tempe yang diperoleh dari industri tempe di Desa Wage Kec. Taman Kab. Sidoarjo, bonggol pisang yang telah dihaluskan, larutan gula 750 gr dalam $1500 \mathrm{ml}$ menggunakan air panas dan EM4 yang digunakan sebagai bioaktivator. Setelah semua siap campurkan semua bahan sesuai variasi takaran yaitu takaran A : 2 L limbah cair industri tempe, 250 gr Bonggol Pisang, $75 \mathrm{ml} \mathrm{EM4,} 250 \mathrm{ml}$ larutan gula, takaran B : 2 L limbah cair industri tempe, 500 gr

Bonggol Pisang, $100 \mathrm{ml} \mathrm{EM4,} 250 \mathrm{ml}$ larutan gula dan takaran $\mathrm{C}: 2 \mathrm{~L}$ limbah cair industri tempe, 750 gr Bonggol Pisang, 125 ml EM4, $250 \mathrm{ml}$ larutan gula, masukkan campuran bahan ke dalam reaktor fermentasi. Menutup rapat reaktor dan arahkan selang gas fermentasi ke dalam botol air yang telah diisi air hingga selang tercelup, diamkan selama 14 hari. Setelah 14 hari, dilakukan penyaringan menggunakan kain saring sehingga POC yang di peroleh adalah bersih bebas ampas dan selanjutnya melakukan uji laboratorium kadar $\mathrm{P}, \mathrm{C}$ - Organik, $\mathrm{pH}$ dan N. 


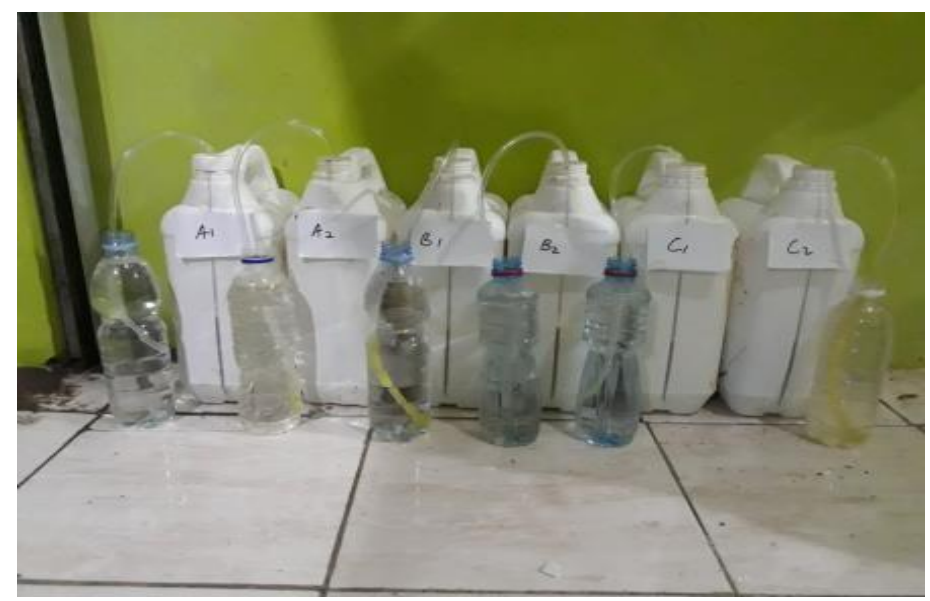

Gambar 1. Proses fermentasi POC pada reaktor

\section{HASIL DAN PEMBAHASAN}

Bonggol pisang memiliki banyak mata tunas yang didalamnya terdapat banyak giberelin dan sitokinin sehingga dapat mengundang mikroorganisme lain untuk datang. Bonggol pisang mengandung beberapa mikroorganisme yang berperan baik dalam penyuburan tanah (Faridah, dkk., 2014). Kadar
Pada Gambar di bawah ini di bawah ini menjelaskan kadar fosfor POC pada masingmasing jenis campuran.

Berikut hasil penelitian dibandingkan dengan Keputusan Menteri Pertanian Nomor 261/KPTS/SR.310/M/4/2019 tentang Persyaratan Teknis Minimal Pupuk Organik, Pupuk Hayati, dan Pembenah Tanah adalah sebagai berikut

Tabel 2. Hasil Penelitian dibandingkan dengan Keputusan Menteri Pertanian Nomor 261/KPTS/SR.310/M/4/2019 tentang Persyaratan Teknis Minimal Pupuk Organik, Pupuk Hayati, dan Pembenah Tanah

\begin{tabular}{|l|l|l|l|l|l|l|}
\hline No & Parameter & Satuan & Standart Mutu & $\begin{array}{l}\text { Sampel } \\
\text { A }\end{array}$ & $\begin{array}{l}\text { Sampel } \\
\text { B }\end{array}$ & $\begin{array}{l}\text { Sampel } \\
\text { C }\end{array}$ \\
\hline 1 & C -Organik & $\%(w / v)$ & Minimum 10 & 2.33 & 2.76 & 2.91 \\
\hline 2 & Hara Makro : N +P2O5 + K2O & $\%(w / v)$ & $2-6$ & 3.38 & 3.53 & 3.66 \\
\hline 3 & N-organik & $\%(w / v)$ & Minimum 0,5 & 1.10 & 1.11 & 1.14 \\
\hline 4 & pH & - & $4-9$ & 3.74 & 3,66 & 3,61 \\
\hline
\end{tabular}




\subsection{Kadar Fosfor Pada POC}

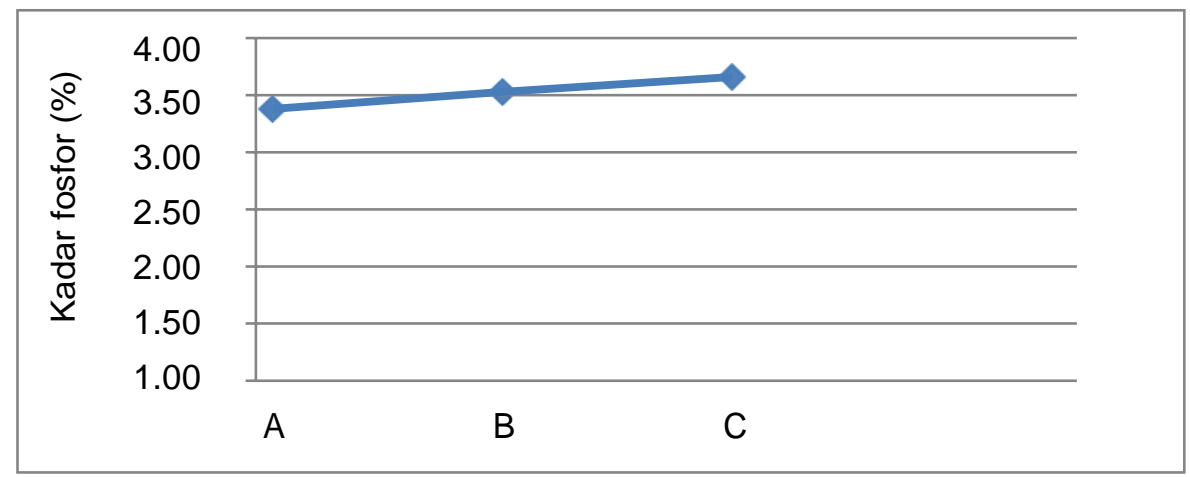

Ket:

A : 2 L limbah cair industri tempe, $250 \mathrm{gr}$ Bonggol Pisang, $75 \mathrm{ml} \mathrm{EM4,} 250 \mathrm{ml}$ larutan gula

B : 2 L limbah cair industri tempe, $500 \mathrm{gr}$ Bonggol Pisang, $100 \mathrm{ml} \mathrm{EM} 4,250 \mathrm{ml}$ larutan gula

$\mathrm{C}: 2 \mathrm{~L}$ limbah cair industri tempe, $750 \mathrm{gr}$ Bonggol Pisang, $125 \mathrm{ml} \mathrm{EM} 4,250 \mathrm{ml}$ larutan gula

Gambar 2. Rerata Hasil Pemeriksaan Kadar Phospor (P)

Peningkatan tertinggi kadar phospor (P) dalam pembuatan pupuk organik cair ini adalah pada perlakuan C (2 L limbah cair industri tempe, 750 gr Bonggol Pisang, 125 ml EM4, $250 \mathrm{ml}$ larutan gula). Tingginya kadar phospor (P) ini bisa jadi di karenakan tingginya kadar $\mathrm{P}$ pada limbah bonggol pisang Direktorat Gizi Departemen Kesehatan R.I., (1996) dan tingginya jumlah EM4 di percobaan ini. Sehingga proses fermentasi yang merombak kandungan fosfor berjalan sempurna, sehingga mengakibatkan kandungan fosfor dalam POC pada perlakuan $\mathrm{C}$ memberikan hasil yang tinggi. Selain itu , semakin besar kadar nitrogen dikandung maka multiplikasi mikroorganisme yang merombak fosfor akan meningkat, sehingga kandungan fosfor dalam pupuk juga meningkat (Nurhapsari, 2012).

Hal ini juga didukung oleh waktu fermentasi dalam pembuatan pupuk organik cair yang kemungkinan sudah mencapai waktu yang optimal di hari ke 14 ini. Pertumbuhan mikroorganisme bergerak kearah fase eksponensial, yaitu pada ke 13 hari, dimana terjadi perubahan sangat cepat terhadap jumlah sel (Meriatna dkk,2019).
Lama waktu fermentasi menentukan tinggi rendahnya kadar $\mathrm{P}$ namun semakin lama waktu fermentasi bukan berarti kadar P juga semakin bertambah karena pada proses fermentasi berhubungan langsung dengan mikroorganisme dimana mikroorganisme memiliki fase stationer. Pada fase ini mikroorganisme mengalami pertumbuhan yang sangat signifikan dan apabila fermentasi dilanjutkan, mikroorganisme akan mengalami kematian dan didapat hasil hara phospor $(\mathrm{P})$ yang lebih sedikit dibanding sebelumnya (Hadisuwito,2013). Menurut Firdaus (2011), kandungan unsur fosfor semakin tinggi dengan terjadinya pelapukan bahan organik yang dikomposkan. Dapat dilihat dari Gambar 2. berdasarkan hasil pemeriksaan laboratorium dapat diketahui bahwa kadar fosfor dari POC adalah rata- rata 3.38-3.66 \%. Dalam hal ini kadar P saudah memenuhi baku mutu yang disyaratkan untuk POC sesuai dengan Permentan No 216 Tahun 2019 tentang baku mutu pupuk organik cair dengan standart $\mathrm{P}$ yaitu $2-6 \%$. 


\subsection{Kadar C Organik Pada POC}

Pada Gambar di bawah ini di bawah ini menjelaskan kadar C Organik POC pada masingmasing jenis campuran.

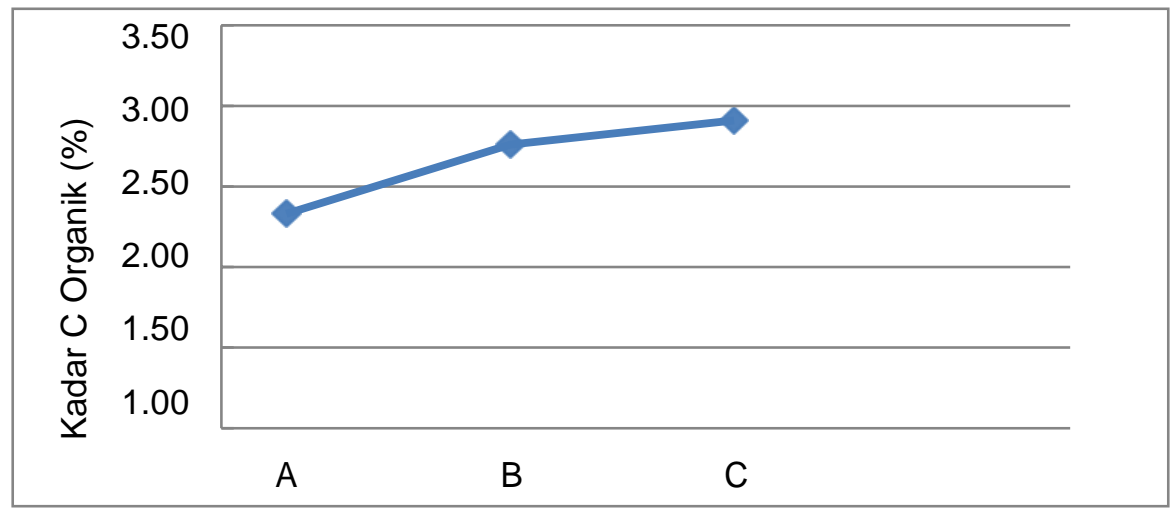

Ket:

A : 2 L limbah cair industri tempe, $250 \mathrm{gr}$ Bonggol Pisang, $75 \mathrm{ml} \mathrm{EM} 4,250 \mathrm{ml}$ larutan gula

B : 2 L limbah cair industri tempe, $500 \mathrm{gr}$ Bonggol Pisang, $100 \mathrm{ml} \mathrm{EM4,} 250 \mathrm{ml}$ larutan gula

$\mathrm{C}: 2 \mathrm{~L}$ limbah cair industri tempe, $750 \mathrm{gr}$ Bonggol Pisang, $125 \mathrm{ml} \mathrm{EM} 4,250 \mathrm{ml}$ larutan gula

Gambar 3. Rerata Hasil Pemeriksaan Kadar C Organik

Peningkatan tertinggi kadar C Organik dalam pembuatan POC ini adalah pada perlakuan $\mathrm{C}$. Tinggi rendahnya kadar $\mathrm{C}$ Organik dalam POC dipengaruhi oleh kandungan karbohidrat yang terdapat pada bahan pembuatan POC yang dalam hal ini diperoleh dari limbah cair rebusan kedelai, bonggol pisang serta larutan gula yang mengandung karbohidrat yang tinggi. Tingginya kadar C Organik pada perlakuan C diduga berasal dari banyaknya penambahan bonggol pisang yang mempunyai kandungan karbohidrat tinggi serta EM4 sebagai bioaktivator sehingga memaksimalkan proses fermentasi. Menurut Sisworo (2006) dalam Herniwati dan Nappu (2012), bahan organik memiliki peranan penting sebagai sumber karbon, dalam pengertian luas sebagai sumber pakan, dan juga sebagai sumber energi untuk mendukung kehidupan dan berkembangbiaknya berbagai jenis mikroorganisme. Menurut Mastar dan Kusnayadi (2016), masing-masing bahan mempunyai C-organik sesuai dengan sifat genetiknya, sehingga semakin banyak karbohidrat pada bahan tersebut maka semakin banyak mengandung C-organik. Menurut Fitria (2008) mikroorganisme alami terdapat dalam EM4 bersifat fermentasi (peragian) terdiri dari lima kelompok mikroorganisme, yaitu bakteri fotosintetik (Rhodopseudomonas sp.), jamur fermentasi (Saccharomyces sp.), bakteri asam laktat (Lactobacillus sp.), dan Actinomycetes. EM4 berguna untuk membantu mempercepat proses pembuatan pupuk organik dan meningkatkan kualitasnya. Penelitian Sri Widyastuti dan Lady Softa (2018) menghasilkan kadar karbon (C) organik sebesar 17,26\%. Dapat dilihat dari Gambar 3. berdasarkan hasil pemeriksaan laboratorium dapat diketahui bahwa kadar C Organik dari POC adalah rata- rata 2.33$2.91 \%$. Dalam hal ini kadar C Organik belum memenuhi baku mutu yang disyaratkan untuk POC sesuai dengan Permentan No 216 Tahun 2019 tentang baku mutu pupuk organik cair 
dengan standart C Organik yaitu 10\%.

\subsection{Derajat Keasaman/pH Pada POC}

Derajat keasaman $(\mathrm{pH})$ merupakan faktor lingkungan yang penting bagi mikroorgansme untuk mendekomposisikan bahan organik yang ada. Selama masa pengomposan $\mathrm{pH}$ diukur setiap 3 hari sekali sampai kompos matang. Adapun $\mathrm{pH}$ yang dihasilkan dalam penelitian ini dapat dilihat pada gambar di bawah ini di bawah ini menjelaskan nilai pH POC pada masing- masing jenis campuran

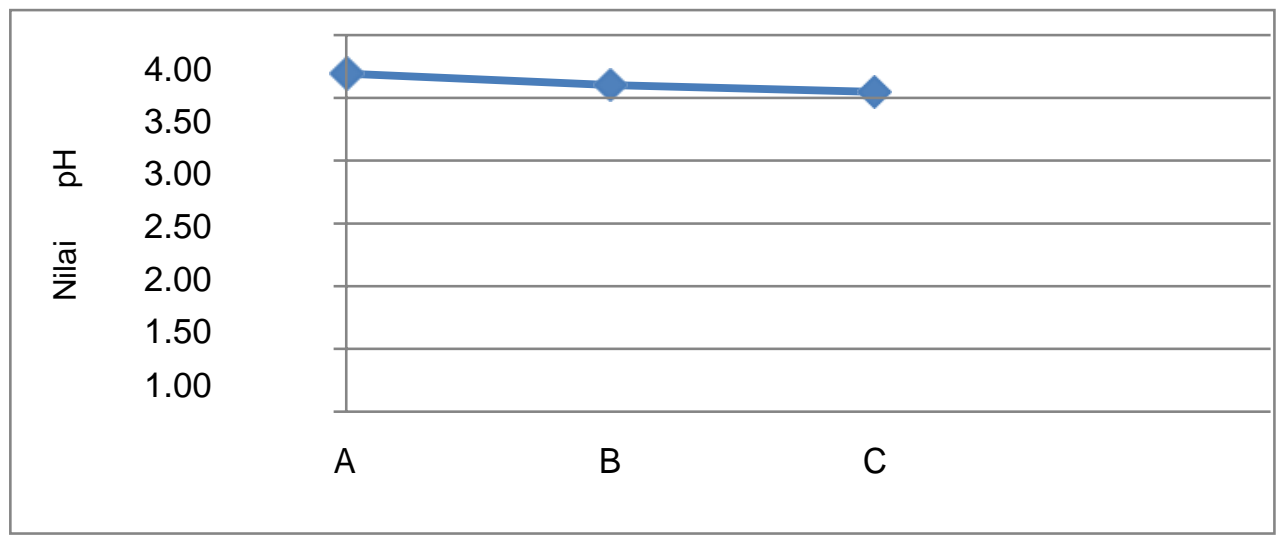

Ket:

A : 2 L limbah cair industri tempe, $250 \mathrm{gr}$ Bonggol Pisang, $75 \mathrm{ml} \mathrm{EM4,} 250 \mathrm{ml}$ larutan gula

B : 2 L limbah cair industri tempe, $500 \mathrm{gr}$ Bonggol Pisang, $100 \mathrm{ml} \mathrm{EM4,} 250 \mathrm{ml}$ larutan gula

$\mathrm{C}: 2 \mathrm{~L}$ limbah cair industri tempe, $750 \mathrm{gr}$ Bonggol Pisang, $125 \mathrm{ml} \mathrm{EM} 4,250 \mathrm{ml}$ larutan gula

Gambar 4. Rerata Hasil Pemeriksaan Nilai pH

Dapat dilihat dari Gambar 4. pisang yang mempunyai kandungan berdasarkan hasil pemeriksaan laboratorium dapat diketahui bahwa nilai $\mathrm{pH}$ dari POC adalah rata- rata 3.61-3.74. Dalam hal ini nilai $\mathrm{pH}$ belum memenuhi baku mutu yang disyaratkan untuk POC sesuai dengan Permentan No 01 Tahun 2019 tentang baku mutu pupuk organik cair dengan standart nilai $\mathrm{pH}$ yaitu 4-9. Dalam proses fermentasi pembuatan POC pada perlakuan C $(2 \mathrm{~L}$ limbah cair industri tempe, 750 gr Bonggol Pisang, $125 \mathrm{ml}$ EM4, $250 \mathrm{ml}$ larutan gula) menghasilkan nilai $\mathrm{pH}$ terendah yaitu 3.61. Hal ini terjadi kemungkinan karena EM4 yang digunakan sebagai bahan bioaktivator pembuatan POC adalah sudah bersifat asam, selain itu banyaknya penambahan bonggol karbohidrat, sehingga menurunkan kadar $\mathrm{pH}$ dalam pembuatan POC. Saat proses dekomposisi bahan organik terjadi aktivitas mikroorganisme yang mengikat sehingga mengakibatkan asam-asam humat meningkat dan ion-ion hidroksil serta fenol yang dihasilkan meningkat (Raihan 2002 dalam Permana 2011). (Desroisir dalam Simbolon, 2008) menyatakan bahwa pada proses fermentasi akan dihasilkan asam- asam yang mudah menguap, diantaranya asam laktat, asam asetat, asam formiat, asam butirat dan asam propinat. Asam- asam ini dihasilkan dari perombakan glukosa dan alcohol. (Jaelani,2015) menyatakan bahwa derajad keasaman $(\mathrm{pH})$ selama proses fermentasi 
dipengaruhi oleh jumlah asam laktat, semakin banyak jumlah bakteri asam laktat maka $\mathrm{pH}$ selama fermentasi akan semakin menurun. Sejalan dengan hal itu Rifan (2009), penurunan $\mathrm{pH}$ selama fermentasi juga disebabkan karena kandungan karbohidrat pada pakan tersedia dalam jumlah yang cukup , sehingga hal ini akan mendukung aktifitas dari bakteri asam laktat untuk mengahasilkan asam-asam organik yang berguna untuk menurunkan $\mathrm{pH}$ dalam kondisi anaerob.

\subsection{Kadar Nitrogen Pada POC}

Limbah cair tempe tersebut memiliki kandungan $\mathrm{N}$ total, $\mathrm{P}$ tersedia, dan $\mathrm{K}$ yang dapat dipertukarkan yang bervariasi. $\mathrm{N}$ total pada limbah cair tempe merupakan jumlah nitrogen total dalam limbah, baik itu organik maupun anorganik. Protein ini kan diuraikan oleh mikroorganisme menjadi senyawa yang lebih sederhana yaitu nitrogen (N) Pawestri Farrah Diba, Eko Budi Susatyo dan Winarni Pratjojo (2013).

Semakin tingginya aktivator yang terkandung pada limbah cair industri tempe, , maka kandungan nitrogennya rendah . Hal ini sesuai dengan penelitian Erwin dan Sabrina (2012) yang menyatakan bahwa pengaruh konsentrasi aktivator memperlihatkan, semakin banyak pemberian aktivator ke dalam bahan kompos semakin kecil kandungan $\mathrm{N}$ kompos yang dihasilkan. Pada Gambar 5. di bawah ini di bawah ini menjelaskan kadar Nitrogen POC pada masing- masing jenis campuran.

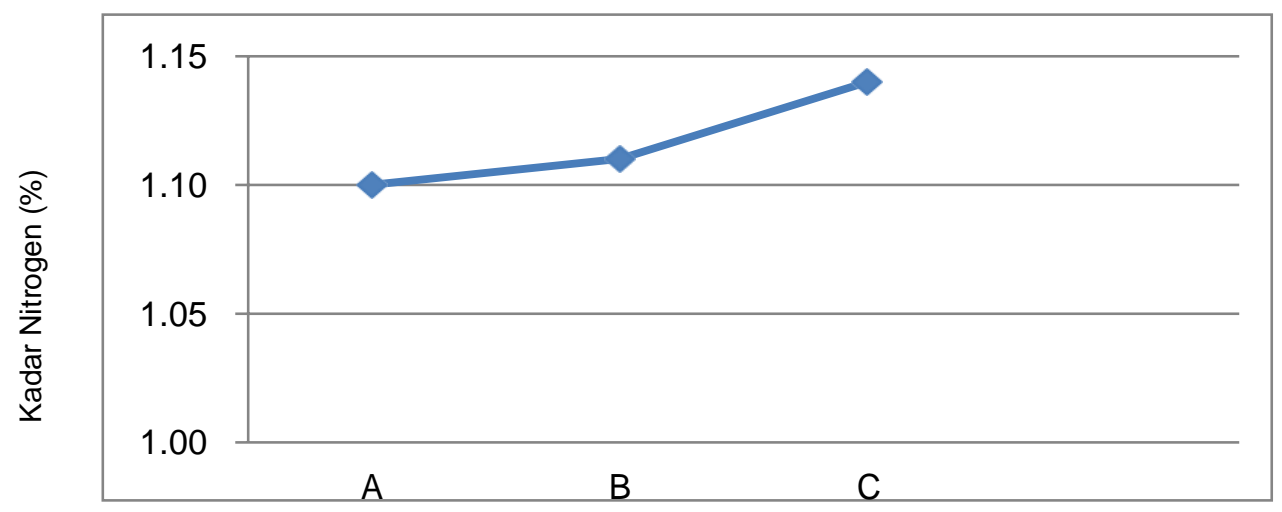

Ket:

A : 2 L limbah cair industri tempe, $250 \mathrm{gr}$ Bonggol Pisang, $75 \mathrm{ml} \mathrm{EM} 4,250 \mathrm{ml}$ larutan gula

B : 2 L limbah cair industri tempe, $500 \mathrm{gr}$ Bonggol Pisang, $100 \mathrm{ml} \mathrm{EM4,} 250 \mathrm{ml}$ larutan gula

$\mathrm{C}: 2 \mathrm{~L}$ limbah cair industri tempe, $750 \mathrm{gr}$ Bonggol Pisang, $125 \mathrm{ml} \mathrm{EM} 4,250 \mathrm{ml}$ larutan gula

Gambar 5. Rerata Hasil Pemeriksaan Kadar Nitrogen

Dapat dilihat dari Gambar 5. berdasarkan hasil pemeriksaan laboratorium dapat diketahui bahwa kadar Nitrogen dari POC adalah rata- rata $1.10-1.14 \%$. Dalam hal ini kadar $\mathrm{N}$ belum memenuhi baku mutu yang disyaratkan untuk POC sesuai dengan Permentan No 01 Tahun 2019 tentang baku mutu pupuk organik cair dengan standart $\mathrm{N}$ yaitu 2-6\%. Dalam hal ini proses fermentasi sudah menghasilkan peningkatan kadar $\mathrm{N}$ dalam pembuatan POC meskipun hasilnya masih rendah. Rendahnya nilai N pada POC kemungkinan diakibatkan karena nilai $\mathrm{N}$ awal pada air rebusan kedelai mempunyai nilai yang rendah. Hasil analisis pabrik industri tempe yang berupa air rebusan kedelai mempunyai nilai N-Total yaitu $677,57 \mathrm{mg} / \mathrm{L}$ (PPKS,2016). Sedangkan peningkatan nilai $\mathrm{N}$ 
ini diduga karena aktivitas mikroorganisme pada proses fermentasi yang optimum dan kandungan protein yang terdapat pada bahan pembuatan POC . Terbukti bahwa pembuatan POC perlakuan $\mathrm{C}$ mempunyai nilai $\mathrm{N}$ tertinggi yang kemungkinan karena penambahan tertinggi EM4 dan bonggol pisang yang mempunyai kandungan protein terdapat pada perlakuan. Tingginya kandungan nitrogen pada pupuk organik cair kombinasi limbah cair tahu, EM4, dan aditif tetes tebu berdasarkan hasil penelitian dikarenakan dalam limbah cair tahu mengandung makronutrient seperti protein (Nandita ,2017).

Berdasarkan hasil penelitian ini berbeda dengan penelitian yang dilakukan oleh Pawestri Farrah Diba, Eko Budi Susatyo dan Winarni Pratjojo (2013), limbah cair tempe difermentasi menggunakan EM-4 dengan variasi hari (4 hari, 8 hari dan 12 hari) dan diperolah limbah cair tempe yang difermentasi selama 8 hari diperoleh kadar $\mathrm{N}, \mathrm{P}$ dan $\mathrm{K}$ tertinggi yaitu $0,22 \%, \quad 0,063 \%$ dan $0,041 \%$. Untuk meningkatkan kadar $\mathrm{N}, \mathrm{P}$ dan $\mathrm{K}$ yaitu dengan penambahan bat guano dengan variasi massa ( $5,10,15,20$ dan 25 gram), limbah cair tempe yang ditambah bat guano 25 gram diperoleh kadar N, P dan K tertinggi yaitu $0,67 \%, 0,15 \%$ dan $0,127 \%$. Sehingga terjadi peningkatan kadar $\mathrm{N}, \mathrm{P}$ dan $\mathrm{K}$ setelah penambahan bat guano 25 gram masing masing sebesar $\mathrm{N}$ $(0,45 \%), \mathrm{P}(0,087 \%)$ dan K $(0,086 \%)$.

Sedangkan hasil penelitian Winda Lepongbulan, Vanny M. A. Tiwow, dan Anang Wahid M. Diah, (2017), kadar unsur hara NPK pada pupuk organik cair dari limbah ikan mujair yang berasal dari danau Lindu yaitu dengan nilai maksimum terhadap variasi volume MOL bonggol pisang dalam penelitian ini yaitu untuk nitrogen (N) sebesar 0,311\% pada penambahan $100 \mathrm{~mL}$ MOL bonggol pisang, phosfor $0,167 \%$ pada penambahan 150 $\mathrm{mL}$ MOL bonggol pisang, dan kalium $0,037 \%$ pada penambahan $150 \mathrm{~mL}$ MOL bonggol pisang.

\section{KESIMPULAN}

Campuran antara $2 \mathrm{~L}$ limbah cair industri tempe dengan bonggol pisang 250 gr hingga
750 gr dan EM4 $75 \mathrm{ml}$ hingga $125 \mathrm{ml}$ dapat memenuhi kandungan Phospor (P) dan Nitrogen $(\mathrm{N})$ dan sebagai pupuk organik cair menurut Peraturan Menteri Pertanian Keputusan Menteri Pertanian Nomor 261/KPTS/SR.310/M/4/2019 tentang Persyaratan Teknis Minimal Pupuk Organik, Pupuk Hayati, dan Pembenah Tanah , sedangkan kandungan $\mathrm{C}$ organik dan $\mathrm{pH}$ tidak memenuhi.

\section{DAFTAR PUSTAKA}

Adiprakoso, D. (2012). Pembuatan Pupuk Organik Cair dan Tepung Pakan Ayam dari Limbah Tempe Menggunakan Bioaktivator EM4. Skripsi. Fakultas Teknik. Program Studi Teknologi Bioproses. Universitas Indonesia. Depok.

Desrosier. (1988). Teknologi Pengawet Pangan. Penerjemah M. Muljoharjo. UI-Press, Jakarta.

Direktorat Gizi Departemen Kesehatan R.I., (1996).

Erwin dan T.Sabrina. 2014. Pengomposan Beberapa Sumber Bahan Organik dan Limbah Padat Industri Perkebunan Dengan Menggunakan Beberapa Jenis dan Konsentrasi Aktivator. Jurnal Online Agroekoteknologi . ISSN No. 2337- 6597 Vol.2, No.3 : 1098- 1106, Juni 2014

Faridah, A., Sumiyati, S. \& Handayani, D. S. (2014). Studi Perbandingan Pengaruh Penambahan Aktivator Agri Simba dengan Mol Bonggol Pisang terhadap Kandungan Unsur Hara Makro (CNPK) Kompos dari Blotong (sugarcane filter cake) dengan Variasi Penambahan Kulit Kopi. Jurnal Teknik Lingkungan, 3(1), 1-9.

Firdaus F. 2010. Kualitas Pupuk Kompos Campuran Kotoran Ayam dan Batang Pisang Menggunakan Aktivator MOL Tapai. http: // repository. ipb.ac. id/ bitstream /handle/123456789/47282/D11ffi_BA B\%20II\%2 0Tinjauan\%20Pustaka.pdf? sequence=6. [20 Agustus 2013]

Fitria, Y. (2008). Pembuatan Pupuk Organik 
Cair dari Limbah Cair Industri Perikanan Menggunakan Asam Asetat dan EM4 ( Effective Microorganism 4),. Skripsi, Bogor : Institut Pertanian Bogor.

Gakoptindo, 2018, Produksi Tempe Melesat Tahun Depan, https://ekbis.harianjogja.com/read/2019 /09/10/502/1017649/gakoptindoproduksi-tempe-melesat-tahun-depan.

Hadisuwito, S. (2012). Membuat pupuk organik cair. AgroMedia.

Hapsari, Nur dan Tjatur Welasih. (2012). Pemanfaatan Limbah Ikan Menjadi Pupuk Organik. Surabaya, FTI, UPN.

Jaelani, A., Widaningsih, N., \& Mindarto, E. (2015). Pengaruh Lama Penyimpanan Hasil Fermentasi Pelepah Sawit oleh Trichoderma Sp Terhadap Derajat Keasaman $(\mathrm{pH})$, Kandungan Protein Kasar dan Serat Kasar. Ziraa'ah Majalah Ilmiah Pertanian, Vol. 40(3), 232-240.

Kusmiadi R, Khodijah NS dan dan Royalaitani, 2015, Penambahan Gedebog Pisang Pada Kompos Bulu Ayam Dengan Berbagai Jenis Aktivator , Enviagro, Jurnal Pertanian dan Lingkungan, April 2015, Vol.8 No. 1, hal 19 - 30 ISSN 1978-1644.

Laboratorium Pusat Penelitian Kelapa Sawit, PPKS. (2016). Hasil Analisis Limbah Pabrik Industri Tempe.

Lindari, N. (2016). Pengaruh Bioaktivator EM4 dan Aditis Tetes Tebu (Molasses) Terhadap Kandungan N,P dan K Dalam Pembuatan Pupuk Organik Cair Dari Limbah Cair Tahu,. Skripsi. Fakultas Teknik. Program Studi Teknik Kimia. Universitas Muhammadiyah. Surakarta.

Maspary. (2012). Apa Kehebatan MOL Bonggol Pisang. http://www.gerbangpertanian.com/2012 /05/apa- kehebatan-molbonggolpisang.html.

Mastar, S. dan Kusnayadi, H. 2016. Kualitas Kompos Berbahan Baku Lokal yang Diaplikasikan dengan Substrat Mikrooganisme Lokal (MOL). Jurnal Ilmu Pertanian Vol. 9(1): 101-112.

Meriatna, M., Suryati, S., \& Fahri, A. (2019).
Pengaruh Waktu Fermentasi dan Volume Bio Aktivator EM4 (Effective Microorganisme) pada Pembuatan Pupuk Organik Cair (POC) dari Limbah Buah- Buahan. Jurnal Teknologi Kimia Unimal, Vol. 7(1), 13-29.

Nappu B. 2011. Efektivitas Penggunaan Beberapa Mikroorganisme Lokal (MOL) dalam Pengolahan Limbah Kakao Menjadi Pupuk Organik dan Aplikasinya pada Tanaman Kakao Produktif.

.http://sumsel.litbang.deptan.go.id/ind/ download/ progutama/ penelitian dan pengkajian/ thn 2011/ EfektifitasPenggunaan-Beberapa-Mikro-

Organisme- Lokal-MOL DalamPengolahan- Limbah- Kakao- Menjadi Pupuk -Organik -dan- Aplikasinya-PadaTanaman-Kakao- Produktif. pdf. [30 September 2013].

Nurosid, 2011. Pupuk Organik Cair Limbah Tempe yang Ramah lingkungan. http://journal.unnes.ac.id/sju/index.php/ ijcs /article/view/1214/1166. Diakses 9 April 2019.

Pawestri Farrah Diba, Eko Budi Susatyo dan Winarni Pratjojo, 2013, Peningkatan Kadar N, P dan K Pada Pupuk Organik Cair Dengan Pemanfaatan Bat Guano , Indo. J. Chem. Sci. 2 (1) (2013).

Permana D. 2011. Kualitas Pupuk Organik Cair dari Kotoran Sapi Pedaging Yang di Fermentasi Menggunakan Mikroorganisme Lokal. [Skripsi]. Bogor: Departemen Ilmu Produksi dan Teknologi Peternakan Fakultas Peternakan, Institut Pertanian Bogor.

Rifan, M. (2009). Perakitan Pupuk N Zeo P Melalui Modifikasi Permukaan Zeolit dan Asidulasi BFA secara Hidrothermal untuk Meningkatkan Produktivitas Tanah Ultisol. Volume 8(1).

Subhan, Nurtika N. (2004). Penggunaan Pupuk NP cair dan Pupuk NPK (15-1515) Untuk Meningkatkan Hasil dan Kualitas Buah Tomat Varietas Oval. Jurnal Hortikultura, Volume 14(4), 254257.

Suhastyo, A. A. (2011). Studi Mikrobiologi 
dan Sifat Kimia Mikroorganisme Lokal yang digunakan pada Budidaya Padi Metode SRI (System of Rice Intensification), Tesis. Sekolah Pascasarjana. Institut Pertanian Bogor. Bogor.

Sri Widyastuti dan Lady Softa Lovakusuma, 2018, Milkfish , Apple And Pineapple Waste As Alternatif Liquid Organic Fertilizer, Proceedings of the $1 \mathrm{st}$ International Conference on Social, Applied Science and Technology in Home Economics (ICONHOMECS 2017) Part of series Advances in Social Science, Education and Humanities Research Publication date March 2018, DOI doi:10.2991/iconhomecs17.2018.31 https://www.atlantispress.com/proceedings/iconhomecs17/25892766

Wahyudin dan Nurhidayatullah, 2018,
Pengomposan Sampah Organik Rumah Tangga Menggunakan Mikroorganisme Lokal Bonggol Pisang Sebagai Bioaktivator , Agriovet Vol.1 No.1 Oktober 2018 ISSN 2654-4792.

Winda Lepongbulan, Vanny M. A. Tiwow, dan Anang Wahid M. Diah, 2017, Analisis Unsur Hara Pupuk Organik Cair Dari Limbah Ikn Mujair R (Oreochromis mosambicus) Danau Lindu Dengan Variasi Volume Mikro Organisme Lokal (MOL) Bonggol Pisang, J. Akademika Kim. 6(2): 92 97, 2017, ISSN 2302-6030 (p), 2477 $5185(e)$.

Wulandari AS, Mansur I, Sugiarti H, 2011, Pengaruh Pemberian Kompos Batang Pisang Terhadap Pertumbuhan Semai Jabon (Anthocephalus cadamba Miq), Jurnal Silvikultur Tropika Vol. 03 No.1 Hal

:78-81. 